\title{
Impact of tourist and one-day visitor arrivals on economic growth. Case study of the Cayman Islands
}

\begin{abstract}
The Cayman Islands are one of the SISODs, located in the Caribbean Sea, with a high number of foreign visitor arrivals and a GDP based to a large extent on tourism. They are also considered to be SITE islands and may even be characteristic of the subtype, PROFIT-SITE islands. The aim of the article is to provide an answer to the question of whether the increase in the number of tourist and one-day visitor arrivals ${ }^{1}$ had a positive impact on the creation of GDP in the Cayman Islands during the period 1983-2011. The hypothesis was that such a correlation should exist and it should be a strong positive correlation, but only between the increase in number of tourist arrivals and increase in GDP. The second question was: which year is the most economically affected by the increase in tourist and visitor arrivals (the same or the following year)? The hypothesis was that the biggest impact is recorded in the year in which the increase in tourist and visitor arrivals occurs (not in the following year). The third question was: has the global economic crisis affected the tourism sector in the Cayman Islands? The hypothesis was that the Cayman Islands were not as badly affected by the global economic crisis as other SISOD countries. The methods used by the author were literature analysis, data analysis and the Spearman correlation ratio.
\end{abstract}

Keywords

Tourism economy • tropical islands • impact of tourism • the Cayman Islands

(C) University of Warsaw - Faculty of Geography and Regional Studies

Introduction

Much research has been conducted about the importance of tourism to the economy of particular regions, countries (Wagner 1997; Smith 2000; Balaguer \& Cantavella-Jorda 2002; Sugiyarto, Blake \& Sinclair 2003; Dritsakis 2004), and especially island territories (Archer 1995; Briguglio 1995; Archer \& Fletcher 1996; Armstrong \& Read 2000; McElroy 2006; Bertram \& Poirine 2007; Shareef, Hoti \& McAleer, 2008; Ehounou \& McElroy 2008; Podhorodecka 2008; Parry \& McElroy 2009; McElroy \& Perri 2010; Seetanah 2010). New and old approaches to evaluating the economic effects of tourism were widely discussed in the work of Dwyer, Forsyth \& Spurr (2004). Papers by Kim, Chen \& Jang (2006, p 931) and Wang (2009, p 75) examined the impact of events related to the economic crisis on the tourism industry.

The economic impact of tourism can be assessed by an input-output analysis, which provides only partial information for policy purposes, having both strengths and weaknesses (Archer 1995). An alternative approach is to use a social accounting matrix (SAM). SAM provides advantages, such as describing the structure of the economy and linking production, income distribution and demand (Wagner 1997, p 593)2.

\footnotetext{
'According to UNWTO, 'same-day visitor' refers to a 'visitor who does not spend night in a collective or private accommodation in the place visited'; 'tourist' - 'a visitor who stays at least one night in a collective or private accommodation in the place visited, 'visitor' - 'refers to any person traveling to a place other than that of his/her usual environment for less than 12 consecutive months and whose main purpose of trip is other than the exercise of any activity remunerated from within the place visited (Concepts, definitions 1995, pp 12-17).

${ }^{2}$ The mentioned methods, input-output analysis and SAM matrix, are not calculated in this article.
}

\author{
Katarzyna Podhorodecka \\ Institute of Regional and Global Studies \\ Faculty of Geography and Regional Studies \\ University of Warsaw \\ e-mail: kpodhorodecka@uw.edu.pl \\ Received: 28 October 2013 \\ Accepted: 26 February 2014
}

No other economic activity but tourism "cuts across so many sectors" and has a positive or negative impact connected with such dependence (Making Tourism Work 2004, p 16). For many tropical islands, tourism has become the main economic activity. Tourism creates both income and employment opportunities. Tourism is also the major foreign exchange generator and it is important for a well-balanced economy. The multiplier effect of tourism ${ }^{3}$ gives the economies of island territories a chance to develop (Making Tourism Work 2004, p 11, p 25). The results of B. Seetanah's (2010) analysis of 19 tourist islands showed that tourism development is an important factor in explaining the economic growth of islands.

Interesting results were shown by Holzner (2010, p 929). An analysis of 134 countries showed that countries with a GDP more dependent on tourism have a faster pace of growth than others ${ }^{4}$. Additionally, countries with higher income from tourism have higher levels of investment.

The main aim of the article is to find an answer to the question: did the increase in the number of tourist and one-day

${ }^{3}$ The multiplier effect in tourism - 'the total increase in output, labor earnings, and employment through inter industry linkages in a region as a result of tourism expenditures' (Frechtling \& Horvát 1999).

${ }^{4}$ Results after controlling the traditional growth-explaining variables (physical and human capital and initial output). 
visitor arrivals have a positive impact on the creation of GDP in the Cayman Islands during the period 1983-2011. The hypothesis was that a strong positive correlation should exist between the increase in number of tourist arrivals and increase in GDP. The second question was: which year is the most economically affected by the increase in tourist and visitor arrivals the same year or the following year? The second hypothesis was that the biggest impact is recorded in the year in which the increase in tourist and visitor arrivals occurs. The third question was: has the global economic crisis affected the tourism sector in the Cayman Islands? The third hypothesis was that Cayman Islands were not as badly affected by the global economic crisis as other SISOD countries. This analysis in this article is based on data provided by UNWTO, the World Bank, the United Nations and the Economics and Statistics Office, Ministry of Finance of the Cayman Islands. The methods used in the article were: literature analysis, data analysis and the Spearman correlation ratio.

The structure of this paper is as follows: the aims and hypothesis are explained in the introduction, the characteristics of the Cayman Islands as a tourist destination are provided in the first chapter and the statistics of one-day visitor and tourist arrivals on the Cayman Islands are shown in the second chapter. The third chapter presents the economic impact of one-day visitor and tourist arrivals. In the fourth chapter the empirical analysis is displayed, along with findings and discussions. The analysed statistical data are provided in the appendix.

\section{The Cayman Islands as a tourist destination}

The Cayman Islands were chosen because they have a high ratio of tourism intensity compared to other countries and especially compared to SISODs ${ }^{5}$ (the number of foreign visitor arrivals exceeds the number of citizens 30 -fold $)^{6}$. Although these islands do not have a big population, they are an important destination for tourists and cruise passengers (Jędrusik 2005, p 181).

SISODs have a very high index of vulnerability due to insularity and remoteness (Briguglio 1995, p 1615). The countries face an additional threat because of geographical dispersion, vulnerability to natural disasters and a limited domestic market. According to Briguglio, small country size can be economically disadvantageous because of limited natural resources, limitations on import-substitution, dependence on export and small range of products and limited opportunity to create economies of scale. Problems also exist relating to low domestic competition and costs of public administration. Economic fragility and economic constraints of SISODs have very often been underlined. SISODs have a higher vulnerability index than other developing countries.

The Cayman Islands are a British Overseas Territory located in the Caribbean Sea, south of Cuba. They are also a tropical island territory with one of the greatest ratios of tourism movement intensity. They are a very good example of a group of islands whose economy relies on tourism. The territory includes 3 islands: Grand Cayman, Little Cayman and Cayman Brac. The territory is considered to be a very important global offshore financial centre. It has an area of about 250 square kilometres and a population of 55.3 thousand (2011) (The Cayman Islands' 2012). The Caymans are made up of limestone and reefs and located in a very humid tropical climate. The annual rainfall ranges from 2000 to 6000 millimetres. The greatest rainfall occurs during the summer and the average temperature is $26^{\circ}$ Celsius. The hurricane season starts in July and lasts until November. Tourism and financial services are the most important elements in the economy of the

${ }^{5}$ SISODs - "small island states or dependencies" - countries or dependent territories which have less than 3 million citizens and an area less than 28 square kilometers. Although they have only $0.3 \%$ of the world's population, they see $4.6 \%$ of total global foreign tourist arrivals (Weaver 1998, p 293).

${ }^{6}$ This is the highest ratio of all island territories (2004).
Cayman Islands. More than $75 \%$ of the population have jobs connected with services. The value of GDP in purchasing power parity per capita is one of the highest in the world (43 202 USD per citizen in 2011) (The Cayman Islands' 2012) ${ }^{7}$.

At the end of 2011, the total population living on the Cayman Islands amounted to 55.5 thousand, 31.3 thousand of whom were citizens of the Caymans (56\% of the total population) and 24.2 thousand citizens were foreigners. The proportion of Cayman Island citizens in the total population decreased over the period 1979-2011. In 1979 the citizens of the Cayman Islands made up $80 \%$ of the population, in 1990 only $65 \%$. In 2000 the tendency was still decreasing to $53 \%$ and in 2005 there was an increase to $61 \%$; however, 2011 saw another decrease (The Cayman Islands' 2012). Many people arrived in the Cayman Islands looking for work. Economic immigrants are very important for this island territory and the labour force must be imported from abroad (Szivas \& Riley 1999, p 751). On the Cayman Islands, immigrants make up approximately $40 \%$ of the population.

The Cayman Islands are a tax haven because of the lack of indirect taxes. On the Islands there are 40 thousand companies and approximately 600 banks and financial corporations registered, whose total assets amount to over 500 billion USD. It is estimated that in the middle of the 1990s employment figures connected with the tax haven amounted to 2.1 thousand people (Hampton \& Christensen 2002, p 1659) $)^{8}$. Due to the fact that tax havens have a negative impact on tax collection in developed countries, there is an opinion that "tax havens may serve as a safeguard against a predisposition of national governments to abuse their monopoly position when designing tax regimes" (Preuss 2012, p. 3 after Hufbauer 1992).

Moreover, various other factors, such as environmental disasters, ethnic conflicts and terrorism, may have an effect on the number of tourist arrivals and the pace of economic growth (Shareef \& McAleer 2005, pp. 313-314). According to the World Travel and Tourism Council, the tourism economy is responsible for approximately $24 \%$ of GDP and $21 \%$ of export on the Cayman Islands $^{9}$ (Travel \& Tourism Economic 2013) However, tourism promotion is only provided for exclusive markets (mainly North America $)^{10}$.

On the Cayman Islands cruise ship passengers constitute a high proportion of all visitors. Nevertheless, these passengers do not provide wide range of work for local people and have only a small influence on the increase of GDP on the islands. Cruise ship passengers are not interested in local culture or tradition ${ }^{11}$. They spend most of their money on goods which are imported to the island and are relatively cheap because of low taxes and tax free zones (alcohol, perfumes, and jewellery).

One-day visitor and tourist arrivals on the Cayman Islands In the year 2011, the Cayman Islands were visited by 1.7 million visitors, only 309 thousand of whom were tourists and 1.4 million passengers of cruise ships. Compared to 2010, there was a decrease of $9.4 \%$ in the number of foreign visitor arrivals and a $7.2 \%$ increase in the number of foreign tourist arrivals. The Cayman Islands recorded the greatest number of visitor arrivals in the year 2006: 2.2 million; in 2007 and 2008 there was a

\footnotetext{
${ }^{7}$ On the Cayman Islands most food must be imported from abroad. There are crops of coconut palm, mango, banana, rice, corn, batatas and tomatoes. Cows, pigs, sea turtles and tropical fish are bred.

${ }^{8}$ In 1997 a stock exchange was opened on the Cayman Islands. ${ }^{9}$ Data for 2013

${ }^{10} \mathrm{~A}$ new flight connection with Boston operated by Cayman Airways stimulated tourism movement from the United States (Tourism Market Trends - Americas, 2006). ${ }^{11}$ Cruise tourism is not only a means of transport but also a destination in itself. A cruise ship tends to be a floating hotel and there is no necessity for passengers to change accommodation (Making Tourism Work 2004).
} 


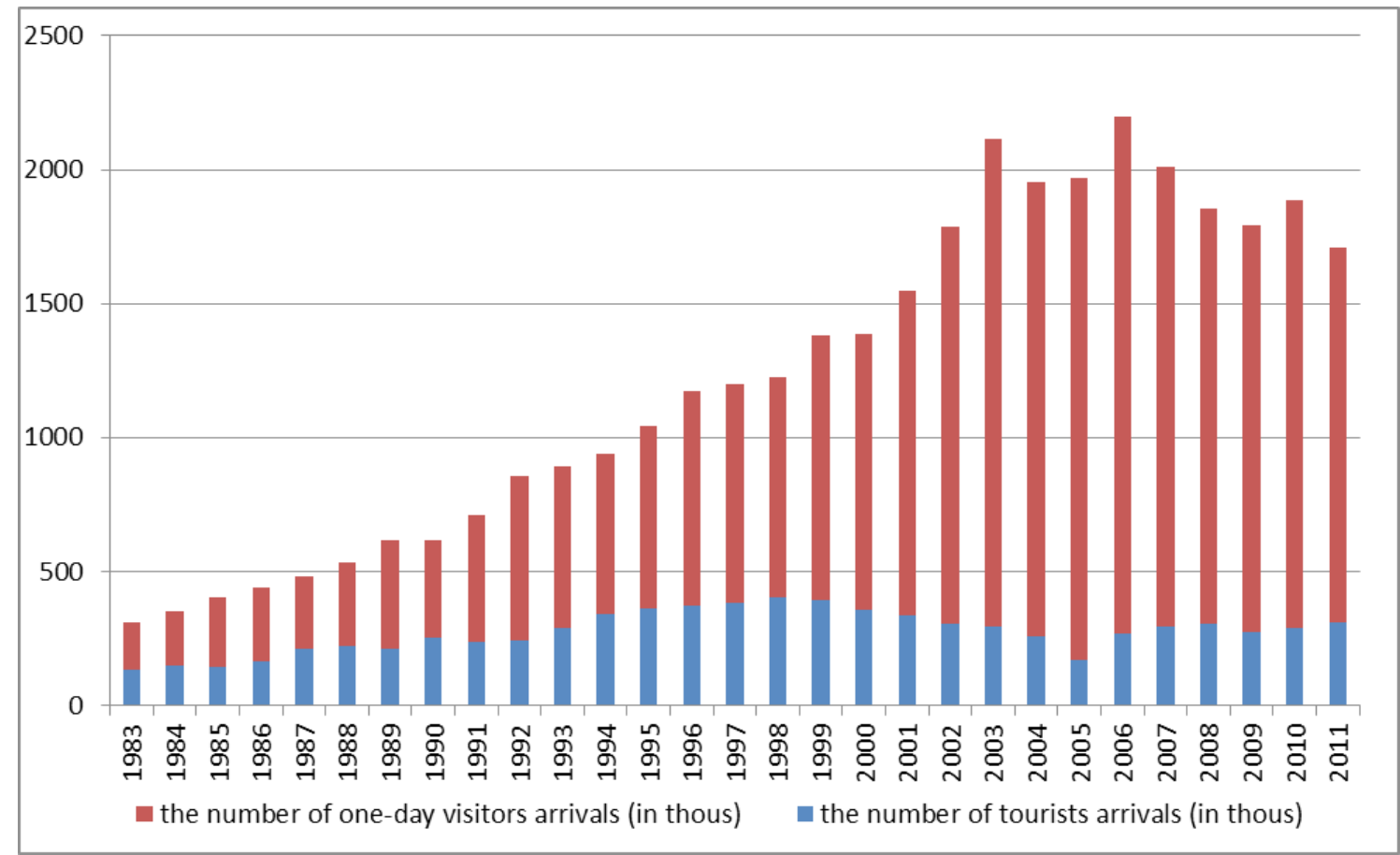

Figure 1. Number of visitor arrivals (tourists and one-day visitors) over the period 1983-2011 (thousands) Source: own elaboration based on UNWTO database (World Tourism Organization UNWTO 2013)

significant decrease in the number of visitor arrivals (1.86 million visitor arrivals were recorded in 2008, which was a decrease of $11 \%$ compared to 2007). The decrease from 2008 to 2011 has its source in the global economic crisis which greatly affected the American market. Americans generally made fewer foreign tourist trips (Fig. 1).

The average daily expenditure of foreign tourists on the Cayman Islands was double the expenditure of cruise ship passengers. Tourists and one-day visitors come mainly from the United States (in 2010 they made up almost $80 \%$ of visitors), Canada (7\%), Great Britain (5\%), and other European countries $(2 \%)^{12}$.

Seasonality of tourist movement on the Cayman Islands is very small. The month with the highest occupancy rates in hotels is March (81\% in 2011), whereas the months with the lowest occupancy are November $(62.1 \%$ in 2011$)$ and October $(62.4 \%$ in 2011).

Analysing different kinds of accommodation, one can distinguish two categories of tourists: those who stay on the Cayman Islands in hotels (staying on average 4.4 nights) and those who stay in apartments (staying on average 6.8 nights $^{13}$ ). Occupancy rates and average length of stay on the Cayman Islands over the period 1995-2010 are shown in table 2.

The number of rooms in tourist accommodation on the Cayman Islands in 2011 was 5 thousand, 2 thousand of which were located in hotels and 2.5 thousand in apartments and private lodgings. Table 2 indicates tourist accommodation on the Cayman Islands over the period 1992-2010.

Total labour force on the Cayman Islands in 2011 was estimated at 37.6 thousand, which was 0.8 percent higher than in 2010. It is estimated that 3 thousand of those were working

${ }^{12}$ National Tourism Organization - the Cayman Islands Department of Tourism has 6 agencies abroad. They are located in the United States (Miami, New York, Houston, and Chicago), Canada (Toronto) and Great Britain (London) (www.caymanislands.ky 3.12.2006). Tourism is mainly promoted in these markets.

${ }^{13}$ Data from 2011 (Tourism, Statistical Compendium 2011). in the tourism industry ${ }^{14}$. It is important to underline that the unemployment rate on the Cayman Islands is very small compared with other countries. In 2011 the unemployment rate was $6.3 \%$, which was double that of the period before the economic crisis (e.g. only $3.5 \%$ in 2004).

\section{Economic impact of one day visitor and tourist arrivals}

The arrival of tourists and one-day visitors provides income for the local economy of the Cayman Islands. Tourists spend money on accommodation, food (especially catering services and purchasing food products and beverages) and transport (including purchasing tickets or renting a car). They also spend money on sport, recreation and shopping (e.g. souvenirs and alcohol).

It should be underlined that the concept of the "tourism industry"15 is defined as "tourism in a small dimension". According to the World Travel and Tourism Council (WTTC), the tourism industry includes only the direct contribution. Only those expenditures made by tourists and one-day visitors on goods and services connected strictly with tourism were taken into account e.g. expenditures on hotels and restaurants, travel agencies.

Tourism economy ${ }^{16}$ creates also additional work places. It is estimated that one job in tourism additionally creates 3 to 4 jobs in other sectors connected with tourism.

${ }^{14}$ Estimations made on the basis of WTTC data.

${ }^{15}$ According to WTTC, 'the tourism industry' includes 'spending on travel and tourism by residents and non-residents for business and leisure purposes as well as government individual spending'. The direct contribution is characteristic for 'sectors such as hotels, airlines, airports, travel agents and leisure and recreation services that deal directly with tourists' (Travel \& Tourism 2013).

${ }^{16}$ According to WTTC, 'tourism economy' includes 'not only expenditures connected strictly with tourism but also those connected indirectly with tourism - those expenditures which wouldn't be made if not for tourism (e.g. expenditures of visitors on transport, food, fuel, insurance)'. 'The indirect effects of the influence of tourism come from the activity of other branches not strictly connected with tourism (e.g. agriculture, construction and many others) and those elements of GDP and employment which would be non-existent without tourism)' (Travel \& Tourism 2013). 
Table. 1. Occupancy rates and average length of stay on the Cayman Islands over the period 1995-2010

\begin{tabular}{|c|c|c|c|c|}
\hline & \multicolumn{2}{|c|}{ Occupancy Rates (\%) } & \multicolumn{2}{c|}{ Average Length of Stay (days) } \\
\hline Year & Hotels & Apartments & Hotels & Apartments \\
\hline $\mathbf{1 9 9 5}$ & 75.3 & 53.9 & 4.7 & 7.8 \\
\hline $\mathbf{1 9 9 6}$ & 66.1 & 51.0 & 4.6 & 7.3 \\
\hline $\mathbf{1 9 9 7}$ & 66.9 & 48.2 & 5.8 & 7.0 \\
\hline $\mathbf{1 9 9 8}$ & 73.1 & 52.3 & 4.7 & 5.8 \\
\hline $\mathbf{1 9 9 9}$ & 71.8 & 46.9 & 4.6 & 7.0 \\
\hline $\mathbf{2 0 0 0}$ & 62.4 & 46.8 & 4.5 & 7.3 \\
\hline $\mathbf{2 0 0 1}$ & 55.3 & 43.1 & 4.8 & 7.3 \\
\hline $\mathbf{2 0 0 2}$ & 50.6 & 40.2 & 4.7 & 6.8 \\
\hline $\mathbf{2 0 0 3}$ & 51.2 & 37.7 & 4.9 & 6.7 \\
\hline $\mathbf{2 0 0 4}$ & 61.7 & 43.1 & 4.9 & 6.6 \\
\hline $\mathbf{2 0 0 5}$ & 55.8 & 46.0 & 4.5 & 6.7 \\
\hline $\mathbf{2 0 0 6}$ & 59.4 & 40.7 & 4.7 & 6.4 \\
\hline $\mathbf{2 0 0 7}$ & 61.7 & 42.5 & 4.5 & 6.9 \\
\hline $\mathbf{2 0 0 8}$ & 62.2 & 44.0 & 4.4 & 6.8 \\
\hline $\mathbf{2 0 0 9}$ & 59.0 & 43.9 & 4.4 & \\
\hline $\mathbf{2 0 1 0}$ & 68.2 & 44.1 & & \\
\hline
\end{tabular}

Source: Tourism, Statistical Compendium 2011.

Table. 2. Tourist accommodation on the Cayman Islands over the period 1992-2010

\begin{tabular}{|c|c|c|c|c|c|c|c|}
\hline \multirow[b]{2}{*}{ Year } & \multicolumn{3}{|c|}{ Hotels } & \multicolumn{3}{|c|}{ Apartments and private lodgings } & \multirow{2}{*}{$\begin{array}{c}\text { All bed- } \\
\text { places }\end{array}$} \\
\hline & $\begin{array}{l}\text { Number } \\
\text { of hotels }\end{array}$ & $\begin{array}{l}\text { Number } \\
\text { of rooms }\end{array}$ & $\begin{array}{l}\text { Number of } \\
\text { bed-places }\end{array}$ & $\begin{array}{l}\text { Number of apartments } \\
\text { and private lodgings }\end{array}$ & $\begin{array}{l}\text { Number of } \\
\text { rooms }\end{array}$ & $\begin{array}{l}\text { Number of } \\
\text { bed-places }\end{array}$ & \\
\hline 1992 & 22 & 1798 & 3596 & 827 & 1476 & 2952 & 6548 \\
\hline 1993 & 24 & 1844 & 3688 & 838 & 1580 & 3160 & 6848 \\
\hline 1994 & 27 & 1940 & 3880 & 841 & 1592 & 3184 & 7064 \\
\hline 1995 & 29 & 1987 & 3974 & 941 & 1840 & 3680 & 7654 \\
\hline 1996 & 29 & 2295 & 4590 & 936 & 1837 & 3674 & 8264 \\
\hline 1997 & 30 & 2331 & 4662 & 1081 & 2146 & 4292 & 8954 \\
\hline 1998 & - & 2075 & 4150 & 870 & 2141 & 4282 & 8432 \\
\hline 1999 & - & 1997 & 3756 & 1090 & 2341 & 4682 & 8438 \\
\hline 2000 & 29 & 2776 & 3969 & - & 2453 & 3960 & 7929 \\
\hline 2001 & 30 & 2812 & 4067 & - & 2594 & 4105 & 8172 \\
\hline 2002 & 29 & 2690 & 3960 & - & 2585 & 4022 & 7982 \\
\hline 2003 & 26 & 3774 & 3774 & - & 2576 & 3993 & 7767 \\
\hline 2004 & - & - & - & - & - & - & - \\
\hline 2005 & - & 2205 & - & - & 1700 & - & - \\
\hline 2006 & 20 & 2205 & - & - & - & 1702 & - \\
\hline 2007 & 21 & 2197 & - & - & - & 2287 & - \\
\hline 2008 & 16 & 1959 & - & - & - & 2373 & - \\
\hline 2009 & 22 & 2012 & - & - & - & 2546 & - \\
\hline 2010 & 20 & 2032 & - & - & - & 2555 & - \\
\hline
\end{tabular}

Source: Tourism, Statistical Compendium 2006; Tourism, Statistical Compendium 2011. 
MISCELLANEA GEOGRAPHICA - REGIONAL STUDIES ON DEVELOPMENT

Vol. $18 \cdot$ No. $3 \cdot 2014 \cdot$ pp. 16-25 •ISSN: 2084-6118 • DOI: 10.2478/mgrsd-2014-0013

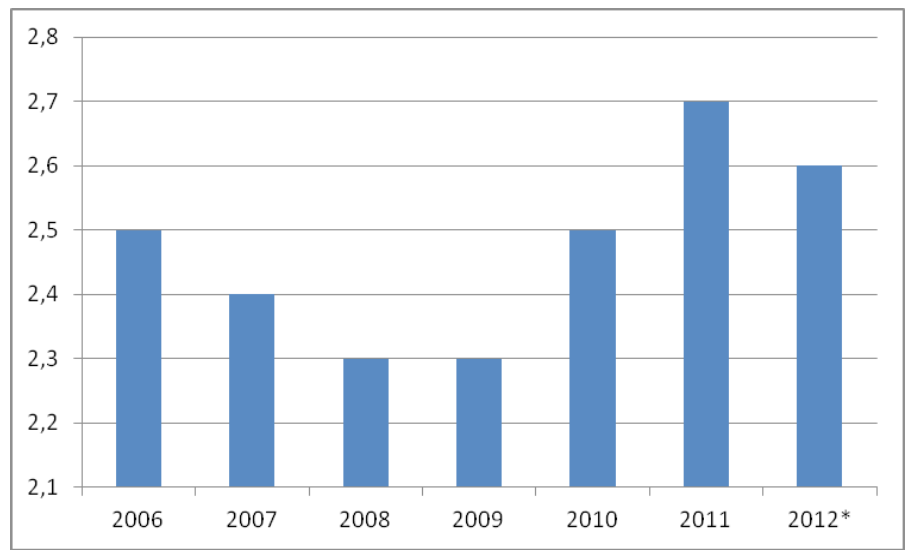

Figure 2. Employment in the tourism industry on the Cayman Islands over the period 2006-2012 (thousands) *Estimations. Source: own elaboration on the basis of Travel and Tourism Economic Impact 2012, Cayman Islands, 2012, World Travel and Tourism Council, London

In 2006, the number of people working in the tourism industry on the Cayman Islands was 2.5 thousand. Over the period 20072009 there was a decrease in the number of people employed in the tourism industry. In 2010 there was an increase in the level to 2.5 thousand and in 2011 a further increase to 2.7 thousand. In 2012 there were 2.6 thousand people working in the tourism industry.

Figure 2 shows employment in the tourism industry on the Cayman Islands over the period 2006-2012.

The percentage of employment on the Cayman Islands in tourism industry in 2012 was estimated at $7.9 \%$ (Travel and Tourism Economic Impact 2012, p 13). Over the period 2006-2008 the proportion was between $7.1 \%$ and $7.3 \%$, there was a slight drop in 2009 to the level of $6.6 \%$ and an increase once again in 2010 and 2011 to the levels of $7.6 \%$ and $8 \%$.

In 2005, the economy of the Cayman Islands recovered after a very dangerous hurricane, Ivan. The number of tourist bedplaces in 2004 decreased due to the hurricane. There was an increase in GDP amounting to $6.5 \%$ in 2005 , but in 2004, when the hurricane hit, the figure was only $0.9 \%$. The economic results were very good despite adverse increases in oil prices. Inflation on the Cayman Islands reached $4.4 \%^{17}$ in 2004 , and $1.3 \%$ in 2011 (but only $0.3 \%$ in 2010). A sharp increase in real estate prices was caused by the limited land area on the island and a very high demand, due to the attractive environment and high intensity of tourist movement (with a high demand especially for investment reasons).

In 2010, the expenditures of foreign tourism in the Caymans amounted to 385 million dollars, which was about $28 \%$ lower than in 2009. The value of visitor expenditure per person in 2010 was USD 225, which was $20 \%$ lower than in 2009. The value of visitor expenditure (both tourists and one-day visitors) per citizen in 2010 was USD 6 962, which was very impressive (World Tourism Organization UNWTO 2013).

Research regarding the average tourist expenditures during a cruise has shown that on-board spending accounts for USD 116 per passenger, while spending on land (on excursions and sports activities) accounts for USD 124 per passenger (Cruise Tourism. Current Situation 2010). This means that half of all tourist expenditure stays on ships and does not affect the economies of local islands.

Tourists who stay on a cruise ship spend one or two days in the port where they disembark. They do not spend nights in ports

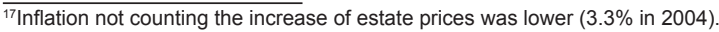

located on the cruise ship routes (they stay on board, so they do not spend money on local hotels and food) (De la Vina \& Ford 1998, p 205) $)^{18}$.

\section{Analysis: Findings and Discussions}

Changes in the number of visitors (one-day visitors and tourists) (in \%) and changes in GDP (in \%) on the Cayman Islands over the period 1984-2011 are shown in Figure 3.

Generally, we observed an average correlation (0.547) between changes in the number of visitor arrivals and changes in GDP on the Cayman Islands. This correlation was not statistically significant ${ }^{19}$. In the years 2004,2007 , and 2008, it was observed that although there was an increase in visitor arrivals, there was a smaller pace of economic growth. A similar growth of both indicators was recorded in 1986, 1988, 1995, 1996, 1999 and 2010. Figure 4 presents changes in the number of tourist arrivals (in \%) and GDP (in \%) on the Cayman Islands over the period 1984-2011

Hypothesis 1: correlation between increase in the number of tourists and one-day visitor arrivals

Although the hypothesis was that the correlation between the increase in the number of tourist arrivals and increase in GDP should be a strong positive one, it was observed that the correlation was only averagely positive (0.477). The correlation was significant at the level of 0.05 . There were several years when there was a decrease in the number of visitor arrivals and an increase in GDP (e.g. from 2000 to 2005). But there were also years when there was both an increase in the number of tourist arrivals and an increase in GDP (e.g. 1986, 1990, 1995, 1998). Interestingly, during the global economic crisis a decrease in number of visitors and tourist arrivals was recorded but there was no decrease in real GDP.

The Spearman correlation between increase in visitor arrivals and increase in GDP was 0.547 , but not statistically significant.

\section{Hypothesis 2: economic impact and time lag}

The correlation between visitor arrivals and GDP growth in the year following the year of recorded arrival was weak (0.296) and was not statistically significant (as suspected in the hypothesis).

${ }^{18}$ Tourists have a direct positive impact on the economy of the country of destination (e.g. increased output of hotels and restaurants), as well as an indirect positive impact (increased output of economic activities supporting the tourism industry). ${ }^{19}$ at the level 0.05 


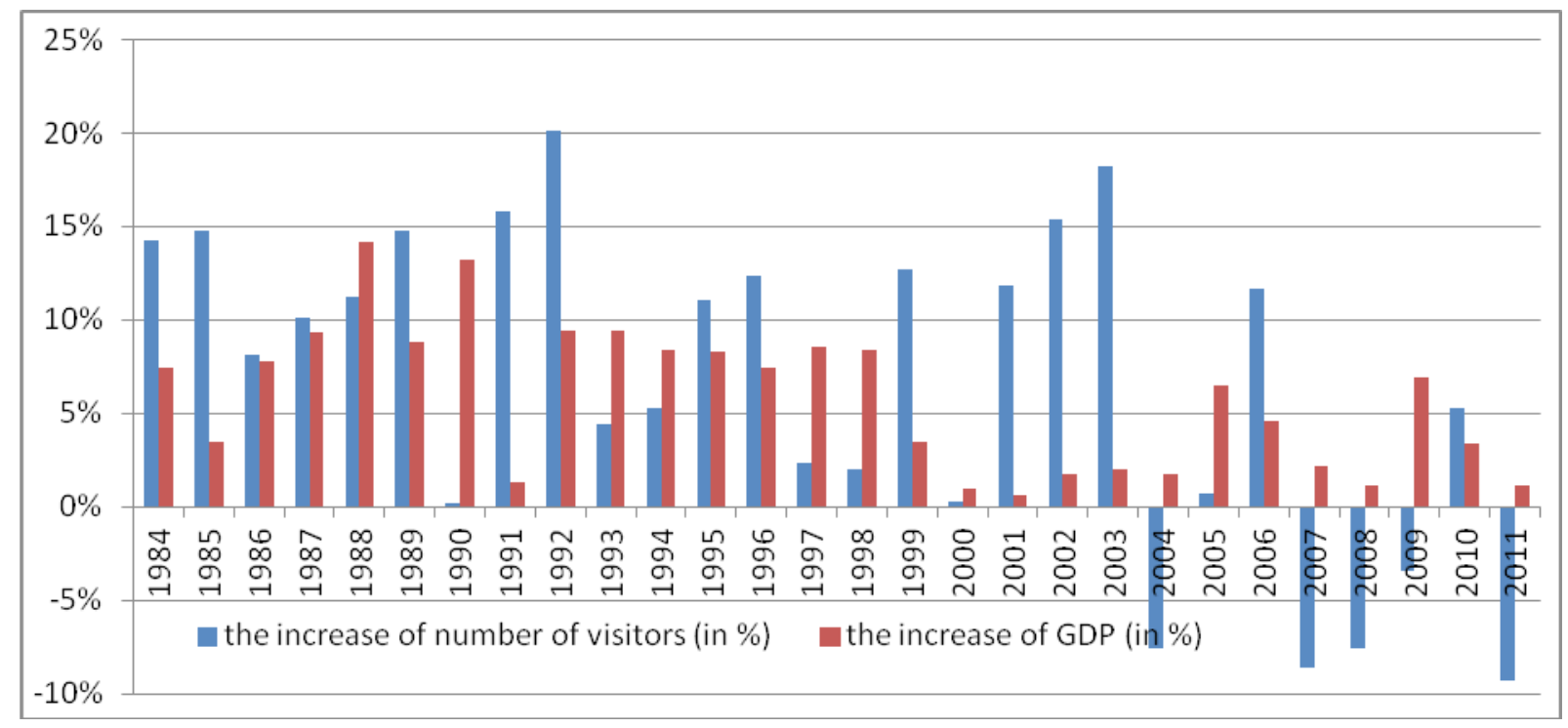

Figure 3. Changes in the number of visitors (one-day visitors and tourists) (in \%) and GDP (in \%) on the Cayman Islands over the period 1984-2011

Source: own elaboration based on data from UNWTO (World Tourism Organization UNWTO 2013), World Bank (World Bank 2012), The Cayman Islands' Annual Economic Report 2011 (and previous editions)

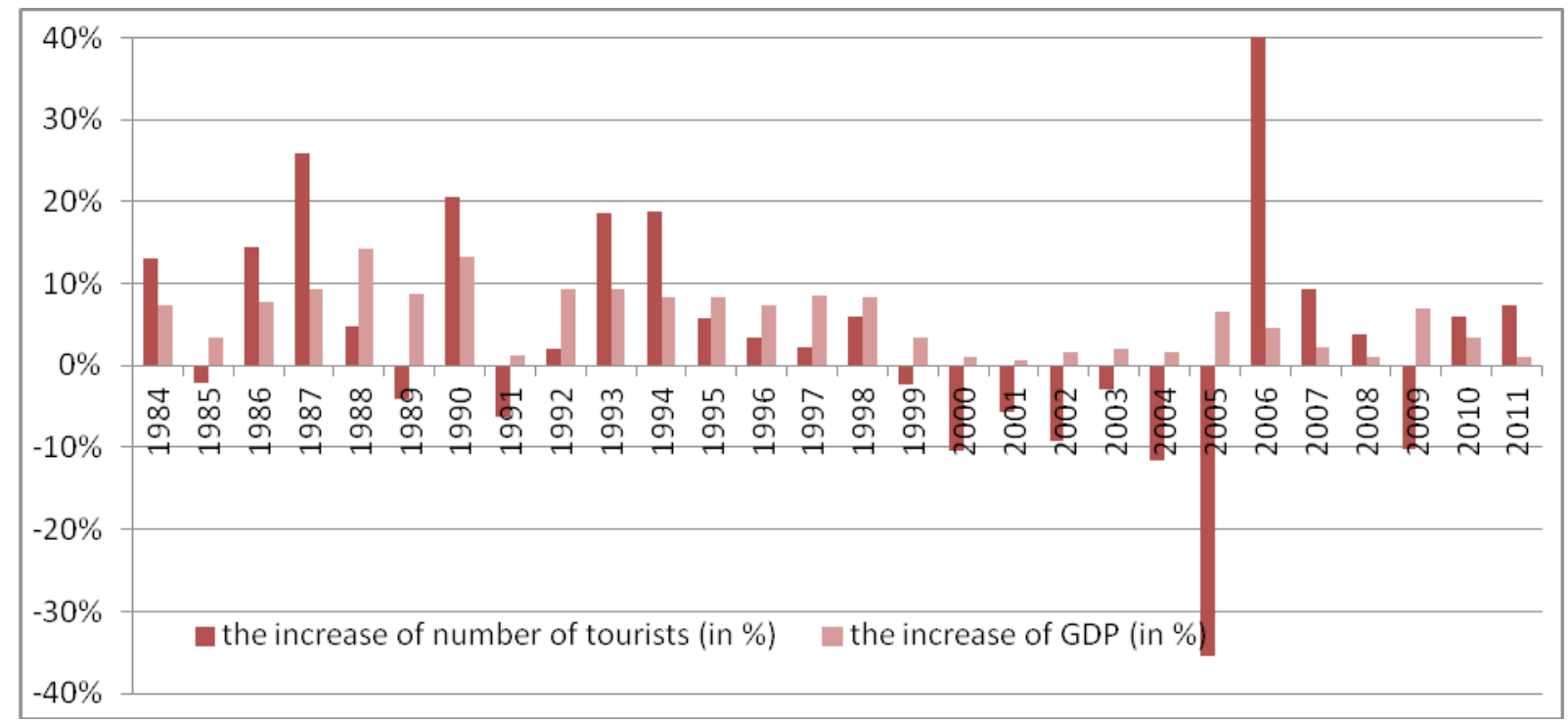

Figure 4. Changes in the number of tourist arrivals (in \%) and GDP (in \%) on the Cayman Islands over the period 1984-2011 Source: own elaboration on the basis of data from UNWTO, World Bank (www.worldbank), The Cayman Islands' Annual Economic Report 2011 (and previous editions)

The correlation between increase in tourist arrivals and increase in GDP in the following year was even weaker (0.151), but not statistically significant. The Spearman correlation ratios between increase in visitor and tourist arrivals and increase in GDP are shown in Table 3.

All analysed data are shown in Appendix 1.

\section{Hypothesis 3: global economic crisis}

The Cayman Islands were not as badly affected by the global economic crisis as other SISOD countries. Although a large decrease in visitor arrivals was observed in the period 2007-2009, there was no registered decrease in GDP in the same period. The decline in visitor arrivals during the global crisis did not have a significant negative impact on the economy of this island territory.
The Cayman Islands compared to other island territories

The Cayman Islands cover a small area and have a small number of citizens when compared to other island territories. However, they are almost first in the ranking of island territory macroeconomic indicators such as GDP in PPP per citizen. The Cayman Islands also rank highly for GDP per citizen created by tourism economy. The unemployment rate in the Cayman Islands is low when compared to other island territories (Podhorodecka 2008, p 196).

The intensity of tourist movement on the Cayman Islands was greater compared to other island territories. During the year, the Cayman Islands were visited by 30 times more visitors than the number of citizens. Tourism economy accounts for a high percentage of GDP and employment, whereas export represents 
MISCELLANEA GEOGRAPHICA - REGIONAL STUDIES ON DEVELOPMENT

Vol. $18 \cdot$ No. $3 \cdot 2014 \cdot$ pp. 16-25 •ISSN: 2084-6118 • DOI: 10.2478/mgrsd-2014-0013

Table 3. Spearman correlation ratio between increase in visitor and tourist arrivals and increase in GDP (in \%)

\begin{tabular}{|c|c|c|}
\hline & \multicolumn{2}{|c|}{ Spearman correlation } \\
\hline & $\begin{array}{c}\text { Correlation between increase in visitor arrivals and } \\
\text { increase in GDP (\%) }\end{array}$ & $\begin{array}{c}\text { Correlation between increase in tourist } \\
\text { arrivals and increase in GDP (\%) }\end{array}$ \\
\hline $\begin{array}{c}\text { In the same year } \\
(\mathbf{n}=28)\end{array}$ & 0.547 & $0.477^{\star}$ \\
\hline $\begin{array}{c}\text { In the following } \\
\text { year (n=27) }\end{array}$ & 0.296 & 0.151 \\
\hline
\end{tabular}

*the correlation is statistically significant at the level of $0.05, n$ - number of analysed years.

Source: own elaboration.

an average percentage. The share of agriculture and industry in the creation of GDP was low when compared to other island territories. However, the share of services in the creation of GDP was the highest out of the analysed island territories.

The length-of-stay ratio, which included the number of days spent by visitors (both one-day visitors and tourists on the Cayman Islands) per 100 citizens, was one of the highest. Urbanization reached one of the highest levels. When compared to the results of other territories, tourism makes up a lower percentage of economy and export than one would expect considering the intensity of tourist movement. However, tourism economy's influence on employment was proportional to the intensity of tourist movement when compared to other island territories.

The Cayman Islands according to the SITE and PROFIT-SITE models

The small island tourism economy (SITE) model was established primarily for the Caribbean islands (McElroy 2010 p. 36). Islands from the SITE model have relatively high GDP per capita. Their GDP structure is dominated by services and in many cases not only tourism but also offshore banking (Shareef 2008). They also have close association between tourism expenditures and GDP growth. The Cayman Islands are one of the island groups that fit this model.

In the work of Parry \& McElroy (2009), a regression analysis of 39 small islands was shown. The features of the most successful SITEs were identified as: political affiliation, relatively low population density, good tourism infrastructure, close location to the major tourism origin markets such as North America, Japan and Europe, and good quality of life. The Caymans were indicated as top SITE performers compared with others e.g. Aruba, Bermuda, St Maarten and the Virgins from the Caribbean region.

According to articles by Oberst and McElroy (2007) and Ehounou \& McElroy (2008), the Cayman Islands are considered to be PROFIT-SITE islands. In Oberst and McElroy, 58 islands with fewer than 3 million citizens were analysed. The territories were divided into two groups based on degree of diversification. The two types were indicated as $23 \mathrm{MIRAB}^{20}$ island territories, which received remittances from emigrants and money from the export of diplomatic services, and 35 PROFIT-SITE economies, which were identified by a dynamic private sector with a strong domestic tourism policy, tax havens and other exports. The results showed that PROFIT-SITE islands have significantly higher income per capita and service employment, and lower unemployment and agricultural share. PROFIT-SITE islands also have a better tourism infrastructure, higher number of tourist arrivals and higher visitor spending per capita.

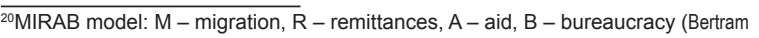
2004; Tisdell 2006)
The vulnerability of small island states to extraneous disasters and crises was confirmed in the literature by Armstrong \& Read (2000). PROFIT-SITE economies also have high social indicator values and high levels of demographic progress compared to the islands from the MIRAB model. PROFIT-SITE islands have populations with higher life expectancy and literacy levels. Moreover, mortality and fertility are lower (Oberst \& McElroy 2007, p 167).

According to Bertram and Poirier (2007, p. 36), the PROFIT-SITE islands gain an advantage over other types of islands due to expanding globalization. The importance of tourism and offshore finance centres are characteristic of the Cayman Islands, which can be distinguished as a subtype of a PROFIT-SITE island. They are very different from the mineral-extraction MIRAB model.

\section{Conclusions}

The Cayman Islands are a very interesting example of an island economy with a substantial tourism impact. High values of tourist expenditure per citizen were observed. The aim of the article was to show whether there is an observable correlation between visitor and tourist arrivals and GDP growth. Data from 1984-2011 was analysed. The correlation between tourist arrival growth and GDP growth was recorded as 0.477 (statistically significant) and the correlation between the growth of visitor arrival and growth of GDP as 0.547 (not statistically significant). Tourists definitely spend more money on islands than one-day visitors during a cruise. Moreover, stronger correlations were recorded in the year of visitor and tourist arrivals than in the following year. This can be explained by the fact that goods and services tourists pay for are bought mainly during trips (not before or after the trip) ${ }^{21}$.

The economy of the Cayman Islands was not as badly affected by the global economic crisis as other SISOD countries. Although there was a large decrease in visitor arrivals recorded in the period 2007-2009, there was no decrease in GDP in this period. As might be suspected, the decline in visitor arrivals during the global crisis did not have a significant negative impact on the economy of the Cayman Islands.

Indicators connected with the tourism economy, such as job creation and tourist expenditure, showed that the Cayman Islands only partially rely on tourism, which has an average influence on economic growth. Cayman Islands are considered to be a small island tourism economy (SITE) because of good economic results, the domination of tourism, services and offshore banking. According to other theories, the Cayman Islands are considered to be PROFIT-SITE islands, because of their dynamic private sector, strong domestic tourism policy and tax haven. The islands are also characterised by a better tourism infrastructure, more 
tourist arrivals per capita and higher proportion of visitors per resident than in other island territories. The article has shown that not all changes in GDP can be explained by changes in tourist arrivals to these islands. Other conditions should also be considered - especially the fact that the Cayman Islands have an economy connected with offshore banking on a large scale. During the global economic crisis a decrease in number of visitors and tourist arrivals was recorded but there was no decrease in real GDP growth. The Cayman Islands' lower level of vulnerability to economic, extraneous disasters can be confirmed by the data given. Many countries and dependent territories which rely on tourism recorded a decrease in GDP connected with the global economic crisis, but the Cayman Islands did not ${ }^{22}$. These islands were an exception during the economic downturn, which might be due to their taking advantage of expanding globalization. During the crisis rich people still want to transfer their money to a tax haven and the Cayman Islands are considered a safe, close and well-known offshore financial centre, especially for citizens of the United States and Canada.
The Cayman Islands have a high degree of involvement in international trade. There is also the element of a lack of cultural differences between tourists who arrive on Cayman Islands and the local inhabitants. There is a greater degree of economic development on the Cayman Islands than other island territories, which, considering the extent of economic globalization, is a good indicator of development.

The Cayman Islands are a British Overseas Territory and, according to research by Bertram (2004), have good GDP results because of political links tying the island to the metropolitan patron as well as to the level of GDP per capita in the metropolitan patron economy. The creation of tourism GDP can also be explained by the political similarities and closeness of language and culture between the local citizens of islands and foreign tourists.

According to Dunn (2011), politically dependent islands have achieved higher levels of welfare and reached higher demographic maturity than independent island countries and the Cayman Islands are a good example of this.

\section{APPENDIX}

Table 1. Number of visitor and tourist arrivals, changes in number of visitor and tourist arrivals and GDP growth over the period 1983-2011

\begin{tabular}{|c|c|c|c|c|c|c|c|c|c|c|c|c|c|c|}
\hline Year & 1983 & 1984 & 1985 & 1986 & 1987 & 1988 & 1989 & 1990 & 1991 & 1992 & 1993 & 1994 & 1995 & 1996 \\
\hline $\begin{array}{c}\text { Number of visitor } \\
\text { arrivals (in thous.) }\end{array}$ & 308 & 352 & 404 & 437 & 481 & 535 & 614 & 615 & 712 & 855 & 893 & 940 & 1044 & 1173 \\
\hline $\begin{array}{c}\text { Number of tourist } \\
\text { arrivals (in thous.) }\end{array}$ & 131 & 148 & 145 & 166 & 209 & 219 & 210 & 253 & 237 & 242 & 287 & 341 & 361 & 373 \\
\hline $\begin{array}{c}\text { Changes in number } \\
\text { of visitor arrivals }\end{array}$ & $14.3 \%$ & $14.8 \%$ & $8.2 \%$ & $10.1 \%$ & $11.2 \%$ & $14.8 \%$ & $0.2 \%$ & $15.8 \%$ & $20.1 \%$ & $4.4 \%$ & $5.3 \%$ & $11.1 \%$ & $12.4 \%$ \\
\hline $\begin{array}{c}\text { Changes in number } \\
\text { of tourist arrivals }\end{array}$ & $13.0 \%$ & $-2.0 \%$ & $14.5 \%$ & $25.9 \%$ & $4.8 \%$ & $-4.1 \%$ & $20.5 \%$ & $-6.3 \%$ & $2.1 \%$ & $18.6 \%$ & $18.8 \%$ & $5.9 \%$ & $3.3 \%$ & $8.4 \%$ \\
\hline \begin{tabular}{c} 
GDP growth \\
\hline
\end{tabular} & $7.4 \%$ & $3.5 \%$ & $7.8 \%$ & $9.3 \%$ & $14.2 \%$ & $8.8 \%$ & $13.2 \%$ & $1.3 \%$ & $9.4 \%$ & $9.4 \%$ & $8.4 \%$ & $8.3 \%$ & $7.4 \%$ \\
\hline
\end{tabular}

\begin{tabular}{|c|c|c|c|c|c|c|c|c|c|c|c|c|c|c|c|c|}
\hline Year & $\mathbf{1 9 9 6}$ & $\mathbf{1 9 9 7}$ & $\mathbf{1 9 9 8}$ & $\mathbf{1 9 9 9}$ & $\mathbf{2 0 0 0}$ & $\mathbf{2 0 0 1}$ & $\mathbf{2 0 0 2}$ & $\mathbf{2 0 0 3}$ & $\mathbf{2 0 0 4}$ & $\mathbf{2 0 0 5}$ & $\mathbf{2 0 0 6}$ & $\mathbf{2 0 0 7}$ & $\mathbf{2 0 0 8}$ & $\mathbf{2 0 0 9}$ & $\mathbf{2 0 1 0}$ & $\mathbf{2 0 1 1}$ \\
\hline $\begin{array}{c}\text { Number of visitor } \\
\text { arrivals (in thous.) }\end{array}$ & 1173 & 1201 & 1225 & 1381 & 1385 & 1549 & 1787 & 2113 & 1953 & 1967 & 2197 & 2008 & 1856 & 1792 & 1886 & 1710 \\
\hline $\begin{array}{c}\text { Number of tourist } \\
\text { arrivals (in thous.) }\end{array}$ & 373 & 381 & 404 & 395 & 354 & 334 & 303 & 294 & 260 & 168 & 267 & 292 & 303 & 272 & 288 & 309 \\
\hline $\begin{array}{c}\text { Changes in number } \\
\text { of visitor arrivals }\end{array}$ & $12.4 \%$ & $2.4 \%$ & $2.0 \%$ & $12.7 \%$ & $0.3 \%$ & $11.8 \%$ & $15.4 \%$ & $18.2 \%$ & $-7.6 \%$ & $0.7 \%$ & $11.7 \%$ & $-8.6 \%$ & $-7.6 \%$ & $-3.4 \%$ & $5.2 \%$ & $-9.3 \%$ \\
\hline $\begin{array}{c}\text { Changes in number } \\
\text { of tourist arrivals }\end{array}$ & $3.3 \%$ & $2.1 \%$ & $6.0 \%$ & $-2.2 \%$ & $-10.4 \%$ & $-5.6 \%$ & $-9.3 \%$ & $-3.0 \%$ & $-11.6 \%$ & $-35.4 \%$ & $58.9 \%$ & $9.4 \%$ & $3.8 \%$ & $-10.2 \%$ & $5.9 \%$ & $7.3 \%$ \\
\hline \begin{tabular}{c} 
GDP growth \\
\hline
\end{tabular} & $7.4 \%$ & $8.6 \%$ & $8.4 \%$ & $3.5 \%$ & $1.0 \%$ & $0.6 \%$ & $1.7 \%$ & $2.0 \%$ & $1.7 \%$ & $6.5 \%$ & $4.6 \%$ & $2.2 \%$ & $1.1 \%$ & $6.9 \%$ & $3.4 \%$ & $1.1 \%$ \\
\hline
\end{tabular}

Source: number of visitor and tourist arrivals - UNWTO Database, GDP growth - World Bank and United Nations, The Cayman Islands' Annual Economic Report 2011 (and previous editions)

\footnotetext{
${ }^{22}$ e.g. in 2009 the GDP growth rate in Antigua and Barbuda was -12\%, in Aruba $-5.6 \%$, the Bahamas $-4.2 \%$, Barbados $-5.3 \%$, Dominica $-1.1 \%$, Fiji $-11 \%$, Jamaica $-3.5 \%$, Kiribati $-2.3 \%$, the Maldives $-3.6 \%$, the Solomon Islands $-1.2 \%$, St. Kitts and Nevis $-6 \%$, St. Vincent and the Grenadines $-2.3 \%$ (World Bank 2012).
} 


\section{References}

Archer, B 1995 'Importance of tourism for the economy of Bermuda', Annals of Tourism Research, vol. 22, no. 4 Elsevier Science Ltd., pp. 918-930.

Archer, B \& Fletcher, J 1996, 'The economic impact of tourism in the Seychelles', Annals of Tourism Research, vol. 23, no. 1, University of Surrey, pp. 32-47.

Armstrong, H W \& Read, R 2000 'Comparing the economic performance of dependent territories and sovereign microstates', Economic Development and Cultural Change, vol. 48, pp. 285-306.

Balaguer, J \& Cantavella-Jorda, M 2002 'Tourism as a longrun economic growth factor. The Spanish case', Applied Economy, no. 34, pp. 877-884.

Bertram, G \& Poirine, B 2007 'Island political economy' in A world of islands: An island studies reader, ed G Baldacchino, Canada and Malta, Institute of Island Studies and Agenda Academic, pp. 332-378.

Bertram, G 2004, 'On the convergence of small island economies with their metropolitan patrons', World Development, vol. 32, no. 2, Victoria University of Wellington, Wellington, New Zealand, pp. 343-364.

Bertram, G 2004, 'The mirab model in the 21st century', Changing Islands - Changing Worlds, Islands of the World, VIII International Conference, Taiwan, pp. 749-781.

Briguglio, L 1995, 'Small island developing states and their economic vulnerabilities', World Development, Elsevier Science Ltd, Great Britain, pp. 1615-1632.

Cayman Islands. Available from <http://www.caymanislands.ky> [3 December 2006]

Concepts, definitions and classification for tourism statistics, 1995, WTO, Madrid, Spain.

Cruise tourism. Current situation and trends, 2010, World Tourism Organization, Madrid

De la Vina, L \& Ford, J 1998, 'Economic impact of proposed cruiseship business', Annals of Tourism Research, Pergamon, pp. 205-208.

Dritsakis, N 2004, 'Tourism as a long-run economic growth factor: An empirical investigation for Greece using causality analysis', Tourism economics, vol. 10, no. 3, pp. 305-316.

Dunn, L 2011, 'The impact of political dependence on small island jurisdictions', World Development, vol. 39, no. 12, Elsevier Ltd, pp. 2132-2146.

Dwyer L, Forsyth, P \& Spurr, R 2004, 'Evaluating tourism's economic effects: new and old approaches', Tourism Management, no. 25, pp. 307-317.

Ehounou, ME \& McElroy, JL 2008, 'The advantages of diversification: Profit/Site versus MIRAB small-island profiles', J.R. Pillarisetti et al. (ed.), Small economies and global economics, New York: Nova Science Publishers, pp. 167-176.

Frechtling, DC \& Horváth E 1999, 'Estimating the multiplier effects of tourism expenditures on a local economy through a regional input-output model', Hospitality, Leisure, Sport and Tourism, Elsevier.

Frechtling, DC 1999, 'The tourism satellite account: foundations, progress and issues', Tourism Management, no. 20, pp. 163-170.

Hampton, M P \& Christensen, J 2002, 'Offshore pariahs? Small island economies, Tax Havens, and the Re-configuration of Global Finance'. World Development, vol. 30, no. 9, pp. 1657-1673.

Holzner, M 2011, 'Tourism and economic development: The beach disease?', Tourism Managment, Elsevier, ScienceDirect, pp. 922-933.
Hufbauer, GC 1992, US Taxation of international income: Blueprint for reform, Washington DC, Institute for International Economics.

Jędrusik, M 2005, Wyspy tropikalne. W poszukiwaniu dobrobytu, Wydawnictwa Uniwersytetu Warszawskiego, Warszawa.

Kim, HY, Chen, MH \& Jang, SS 2006, 'Tourism expansion and economic development: The case of Taiwan', Tourism Management, vol., no. 5, Elsevier, ScienceDirect, pp. 925933.

Making Tourism Work for Small Islands Developing States, 2004, Department of Sustainable Development of Tourism, World Tourism Organization, Madrid

McElroy, JL \& Parry, CE 2010, 'The characteristics of small island tourist economies', Tourism and Hospitality Research, vol. 10, pp. 315-328.

McElroy, JL \& Perri, H 2010, 'SITEs revisited: Socioeconomic and demographic contours of small island tourist economies', Asia Pacific Viewpoint, vol. 51, no. 1, pp. 36-46.

McElroy, JL 2006, 'Small island tourist economies across the life cycle', Asia Pacific Viewpoint, vol. 47, no. 1, pp. 61-77.

Oberst, AJ \& McElroy L 2007, 'Contrasting socioeconomic and demographic profiles of two, small island, economic species: MIRAB versus PROFIT/SITE', Island Studies Journal, no. 2, pp. $164-176$.

Parry, CE \& McElroy, JL 2009, 'The supply determinants of small island tourist economies', The ARA (Caribbean) Journal of Tourism Research, vol. 2, pp. 13-22.

Podhorodecka, K 2008, Turystyka na wyspach strefy międzyzwrotnikowej. Zróżnicowanie roli gospodarczej i jego uwarunkowania, PhD thesis, Warsaw University, Warsaw.

Preuss, L 2012, 'Responsibility in paradise? The adoption of CRS tools by companies domicilied in tax havens', J Bus Ethics, vol. 110, Springer, pp. 1-14.

Seetanah, B 2010, 'Assessing the dynamic economic impact of tourism for island economies', Annals of Tourism Research, vol. 38, no. 1, Elsevier Science Ltd., Great Britain, pp. 291308.

Shareef, R, Hoti, S \& McAleer, M 2008, The economics of small island tourism, Cheltenham, Edward Edgar.

Shareef, R \& McAleer, M, 2005 'Modeling international tourism demand and volatility in small island tourism economies', International Journal of Tourism Research, no. 7, pp. 313333.

Smith, S L J 2000, 'Measurement of tourism's economic impacts', Annals of Tourism Research, vol. 27, no. 2, Pergamon, Great Britain.

Sugiyarto, G, Blake, A \& Sinclair M T 2003, 'Tourism and globalization. Economic impact in Indonesia', Annals of Tourism Research, vol. 30, no. 3, Elsevier Science Ltd., Great Britain, pp. 683-701.

Szivas, E \& Riley, M 1999, 'Tourism employment during economic transition'. Annals of Tourism Research, vol. 26, no. 4, Pergamon, pp. 747-771

The Cayman Islands' Annual Economic Report 2011 (and previous editions), 2012, The Economics and Statistics Office, Ministry of Finance, Tourism \& Development.

Tisdell, C 2006, 'Economic prospects for small island economies, particularly in the South Pacific in a globalising world', Economic Theory, Applications and Issues, Working Paper no. 43, The University of Queensland.

Tourism market trends - Americas 2006, World Tourism Organization, Madrid.

Tourism, Statistical Compendium 2011 (and 2006 edition), 2012, Economic and Statistical Office, The Cayman Islands. 
Travel \& Tourism Economic Impact 2013 World, 2013, World Travel and Tourism Council.

Travel \& Tourism Economic Impact 2013, Cayman Islands, 2013, World Tourism Travel and Tourism Council.

Travel and Tourism Economic Impact 2012, Cayman Islands, 2012, World Travel and Tourism Council, London.

Wagner, JE 1997, 'Estimating the economic impact of tourism', Annals of Tourism Research, vol. 24, no. 3, Elsevier Science Ltd, pp. 592-608.

Wang, T 2009, 'The impact of crisis events and macroeconomic activity on Taiwan's international inbound tourism demands', Tourism Management, Elsevier, no. 30, pp. 75-82.
Weaver, DB 1998, 'Peripheries or the Periphery. Tourism in Tobago and Barbuda', Annals of Tourism Research, vol. 25, no. 2, pp. 292-313.

World Bank. Available from <http://www.data.worldbank.org/ indicator>. [2 February 2012]

World Bank. Cayman Islands. Available from <http://www.data. worldbank.org/country/cayman-islands>. [2 February 2012].

World Tourism Organization UNWTO. Available from <http:// www.unwto.org>. [10 January 2013] 